\title{
Description of Chemical and Biological Soil Characteristics of Two Fields Subjected to Different Agricultural Management under Mediterranean Conditions
}

\author{
Salvatore M. Meli ${ }^{*}$, Vincenza La Porta ${ }^{2}$, Edoardo Puglisi ${ }^{2}$, \\ Attilio A.M. Del Re ${ }^{2}$, Mara Gennari ${ }^{1}$ \\ ${ }^{1}$ Dipartimento di Scienze Agronomiche, Agrochimiche e delle Produzioni Animali \\ Università di Catania, Via Santa Sofia 98, 95123 Catania, Italy \\ ${ }^{2}$ Istituto di Chimica Agraria ed Ambientale, Università Cattolica del Sacro Cuore \\ Via Emilia Parmense 84, 29100 Piacenza, Italy
}

Received: 1 September 2005. Accepted: 7 April 2006

\begin{abstract}
Several factors such as soil pollution and intensive agricultural management continuously damage the sustainability of agricultural production, with potentially adverse effects on soil quality. It is important to create applicable and valid soil quality indicators in order to both identify areas with potential productivity problems and monitor soil quality changes due to a range of perturbations. In this work we compared several chemical and biological variables between a Mediterranean soil characterized by intensive horticulture that has been irrigated for 20 years with moderately saline waters (IM) and an adjacent soil, subjected to a sustainable agricultural production management and irrigated with plain water (SM). Soil sampling was repeated three times during a year in both sites. IM soil had lower $\mathrm{pH}$, organic carbon and total nitrogen compared to SM soil at all sampling times, while its electrical conductivity was significantly higher at two sampling times only. Potentially mineralizable nitrogen pointed out significant differences only at the first sampling time, with lower levels in the SM soil. $\beta$-sitosterol, cholesterol and ergosterol varied significantly with sampling time and were influenced also by management. Statistical approach by Principal Component Analysis highlighted a contrast between two groups of soil variables: potentially mineralizable nitrogen and sterols mainly weighted on the first axis, while chemical properties, weighted on the second one. Moreover, the second axis separated the soil subjected to a sustainable agricultural production system from that subjected to intensive practice management, while the first axis separated the third sampling data from the first two.
\end{abstract}

Key-words: soil management, soil quality indicators, potentially mineralizable nitrogen, sterols, univariate and multivariate statistical analyses.

\section{Introduction}

Soil is a natural resource that is not renewable on a human time scale. Its performance may be maintained in the long term by exploitation compatible with its natural characteristics. Several factors such as contamination by xenobiotics, depletion of soil organic matter, and irrigation with saline waters continuously damage the sustainability of agricultural production, with potentially adverse effects on soil quality (Zalidis et al., 2002). It is important to create applicable and valid soil quality indicators in order to both identify areas with potential productivity problems and monitor soil quality changes due to a range of perturbations (Bolinder et al., 1999).

In the past, physical and chemical properties were preferred as soil quality indicators to biological variables, which were considered too difficult to measure (Arshad and Coen, 1992).

Potentially mineralizable nitrogen (PMN) shows the capacity of the soil to supply plant available $\mathrm{N}$ by the conversion of organic nitrogen to the inorganic forms. It is a useful indicator of soil quality because $\mathrm{N}$ mineralization is strongly influenced by environmental and anthropic induced changes (Duxbury and Nkambule, 1994). 
Sterols, typical components of eukaryotic cells, are good indicators of plant, animal and microbial biomass (Ebraimzadeh et al., 2001; Ibanez et al., 2000; West and Grant, 1987), nevertheless it has been pointed out (Puglisi et al., 2003) that more research is necessary in order to evaluate better the potential use of sterols as indicators of soil quality.

In this work, through the measurement of several chemical and biological properties, we monitored the performance of Mediterranean soils, either intensively cropped and irrigated with moderately saline waters for 20 years (IM), or subjected to a sustainable agricultural production system and irrigated with plain waters (SM). Both univariate and multivariate statistical analyses were performed in order to highlight the crop system effects on different groups of parameters and to identify the more sensitive ones. Soil sampling was performed in two consecutive springs and in the autumn between, in order to take the time effects into account as well.

\section{Materials and methods}

\subsection{Soil and soil sampling}

The study was conducted with two soil collected in the coastal area of Southern Italy, $20 \mathrm{~km}$ from Bari. This area is characterized by Mediterranean climate, with mild rainy winters and warm dry summers (average annual temperature is $16{ }^{\circ} \mathrm{C}$ and average annual precipitation is $535 \mathrm{~mm}$ ). The Intensive Management soil (IM) was clay loam ( sand $=33 \%$, silt $=26 \%$, clay $=41 \%$ ) Alfisol, intensively cropped with tomato (Lycopersicon esculentum Mill.), parsley [Petroselinum crispum (Mill.) Nyman ex A.W. Hill] and several varieties of lettuce (Lactuca sativa L.), with three crop cycles per year and intensive tillage and mineral fertilizing, and with scarce input of organic matter; it has been irrigated for the last 20 years with moderately saline water (electrical conductivity 1.6-4.5 dSm${ }^{1}$ ). The IM soil was compared with a neighbouring Sustainable Management soil (SM) of similar pedology $($ sand $=42 \%$, silt $=24 \%$, clay $=34 \%)$, cultivated with the common fig (Ficus carica L.), with minimum tillage, organic amendment, low pesticide use and it is irrigated only in summer with low-salt waters (Colombo et al., 2002).
In both sites, five soil samples, each consisting of four $3 \mathrm{~kg}$ sub-samples, were taken at a depth of $0-15 \mathrm{~cm}$ from a surface of 1 hectare, following a W scheme. Sampling was repeated three times: April 2000, October 2000 and April 2001. Therefore 10 samples were analysed for each sampling time, giving a total of 30 samples. Samples were sieved at $2 \mathrm{~mm}$ and stored at $4^{\circ}$ $\mathrm{C}$ prior to analysis.

\subsection{Soil chemical measurements}

Soil texture, $\mathrm{pH}\left(\mathrm{H}_{2} \mathrm{O}\right)$, organic carbon, total nitrogen and electrical conductivity of water extract (soil to water ratio 1:5) were measured using the standard methods recommended by Soil Science Society of America (Page et al., 1982).

\subsection{Potentially Mineralizable Nitrogen}

For Potentially Mineralizable Nitrogen (PMN) determination, soil samples were incubated at $30^{\circ} \mathrm{C}$ for 28 days. $\mathrm{NO}_{3}-\mathrm{N}$ and $\mathrm{NH}_{4}-\mathrm{N}$ concentrations in $0.5 \mathrm{M} \mathrm{K}_{2} \mathrm{SO}_{4}$ soil extracts (1:4 soil:extractant $\mathrm{w} / \mathrm{v}$ ratio) were analysed at $0,7,14,21$ and 28 days (Drinkwater et al., 1996). $\mathrm{NH}_{4}-\mathrm{N}$ was determined according to the indophenolblue colorimetric method, while $\mathrm{NO}_{3}-\mathrm{N}$ was reduced to $\mathrm{NO}_{2}-\mathrm{N}$ in a $\mathrm{Cu}-\mathrm{Cd}$ column and quantified according to a modification of the GriessIlosvay method (Keeney and Nelson, 1982).

\subsection{Sterols}

Cholesterol, $\beta$-sitosterol, and ergosterol were extracted with methanol (Grant and West, 1986). The determination of cholesterol and $\beta$ sitosterol was made by GLC-MS after silanization in pyridin with $\mathrm{N}, \mathrm{O}$-bis-(trimethylsilyl) trifluoroacetamide, esamethyldisilazane and trimethylclorosilane in a 0.2:1:2:1 ratio. Ergosterol analysis was performed by LC without prior silanization, to avoid some interference peaks found in GLC-MS (Puglisi et al., 2003). Coprostanol was extracted and analysed by the same techniques used for cholesterol and $\beta$-sitosterol, but it was not detected in any sample.

In the second sampling time sterols data were available in three samples instead of five for each soil. Analysis was repeated three times on three replicates in order to evaluate the internal variability of samples.

\subsection{Data analysis}

All statistical analyses were performed with SAS software (SAS Institute, 1985). 
A mixed model analysis of variance (PROC GLM, SAS Institute 1985), containing fixed and random classification variables, was applied to chemical and biological data in order to assess significant differences between the two soils studied here. A fixed factor has levels that are determined by the operator, while a random factor has levels that are chosen randomly from the population of all possible levels (Sit, 1995). A main effect to be detected and evaluated is normally a fixed factor, while an effect that contributes to the data spread is a random one. The two main factors, namely the effects of cultural practices (classification variable MANAGEMENT) and sampling time (classification variable TIME), and their interaction were investigated. MANAGEMENT was set as a fixed effect, TIME as a random one. The TIME*MANAGEMENT interaction was considered random as well.

With the presence of fixed and random effects, statistical tests become more restrictive and presumably more realistic (Snedecor and Cochran, 1989). All significant effects were confirmed by Tukey's test for comparison of means in a fixed model.

All data were also analyzed with a multivariate reduction technique, principal component analysis (PCA). The PCA technique projects the original data onto new axes (principal components), which condense the main patterns of the multidimensional data swarm. Each principal component extracts a portion of the vari- ance of original data, in decreasing amounts from the first axis upward. Relationships among samples are readily observed by plotting sample scores on the two or three dimensions of the main principal components.

In this work samples were divided into 6 groups, INTENSIVE MANAGEMENT (IM) and SUSTAINABLE MANAGEMENT (SM) soils, at three sampling times. After the PCA, a varimax rotation was performed (PROC FACTOR, SAS Institute 1985) in order to maximize the correlations between the original variables and the axes.

\section{Results and discussion}

\subsection{Soil chemical characteristics}

Mixed model ANOVA of chemical properties revealed some significant differences (Table 1 ). Total nitrogen was the only variable significantly affected by TIME $(P<0.05)$. MANAGEMENT effect (Table 1) significantly affected (at least $P<0.01$ ) $\mathrm{pH}$, organic carbon, and total nitrogen regardless of sampling time. These parameters were lower in IM soil than in SM soil (Table 2). Although organic carbon and total nitrogen were inversely correlated with electrical conductivity of water extracts (respectively $\mathrm{R}^{2}=-0.71$ and $\mathrm{R}^{2}=-0.59, P<0.05$; degrees of freedom $=28$ ), the IM soil did not show sodic properties (Colombo et al., 2002); thus, the drop of organic matter is not due to

Table 1. Results of mixed model ANOVA on the effects of TIME, MANAGEMENT and their interaction (TIME*MANAGEMENT) on the chemical and biological soil characteristics.

\begin{tabular}{|c|c|c|c|c|c|c|c|c|c|c|}
\hline \multirow[t]{2}{*}{ Soil quality indicators } & \multicolumn{3}{|c|}{ Time } & \multicolumn{3}{|c|}{ Management } & \multicolumn{3}{|c|}{ Time $*$ Management } & \multirow{2}{*}{$\frac{\text { Model error }}{\text { Df }}$} \\
\hline & Df & $\mathrm{F}$ & $\mathrm{P}$ & Df & $\mathrm{F}$ & $\mathrm{P}$ & Df & $\mathrm{F}$ & $\mathrm{P}$ & \\
\hline $\mathrm{pH}\left(\mathrm{H}_{2} \mathrm{O}\right)$ & 2 & 6.01 & ns & 1 & 106.12 & $* *$ & 2 & 0.25 & ns & 24 \\
\hline Organic Carbon & 2 & 9.22 & ns & 1 & 309.41 & $* * *$ & 2 & 0.33 & ns & 24 \\
\hline Total Nitrogen & 2 & 62.44 & $*$ & 1 & 342.25 & $* * *$ & 2 & 0.01 & ns & 24 \\
\hline Electrical Conductivity & 2 & 1.22 & ns & 1 & 8.90 & ns & 2 & 3.92 & $*$ & 24 \\
\hline PMN $\delta 28 d$ & 2 & 3.96 & ns & 1 & 0.69 & $\mathrm{~ns}$ & 2 & 25.68 & $* * *$ & 24 \\
\hline Min.- N d0 & 2 & 0.33 & $\mathrm{~ns}$ & 1 & 3.26 & $\mathrm{~ns}$ & 2 & 10.74 & $* * *$ & 24 \\
\hline $\mathrm{NO}_{3}-\mathrm{N}$ d0 & 2 & 0.30 & $*$ & 1 & 2.90 & ns & 2 & 11.58 & $* * *$ & 24 \\
\hline $\mathrm{NH}_{4}-\mathrm{N}$ d0 & 2 & 20.47 & ns & 1 & 2.45 & ns & 2 & 8.70 & $* *$ & 24 \\
\hline Min. N d28 & 2 & 1.18 & $\mathrm{~ns}$ & 1 & 2.03 & $\mathrm{~ns}$ & 2 & 28.82 & $* * *$ & 24 \\
\hline $\mathrm{NO}_{3}-\mathrm{N}$ d28 & 2 & 1.20 & ns & 1 & 1.99 & $\mathrm{~ns}$ & 2 & 28.69 & $* * *$ & 24 \\
\hline $\mathrm{NH}_{4}-\mathrm{N}$ d28 & 2 & 1.27 & ns & 1 & 0.75 & $\mathrm{~ns}$ & 2 & 1.20 & $\mathrm{~ns}$ & 24 \\
\hline Cholesterol & 2 & 32.57 & $*$ & 1 & 4.51 & ns & 2 & 7.62 & $* * *$ & 20 \\
\hline$\beta$-Sitosterol & 2 & 15.20 & ns & 1 & 7.43 & ns & 2 & 2.41 & $\mathrm{~ns}$ & 20 \\
\hline Ergosterol & 2 & 620.42 & $* * *$ & 1 & 38.62 & $* * *$ & 2 & 0.08 & ns & 20 \\
\hline
\end{tabular}

Significant levels: $* \mathrm{P}<0.05, * * \mathrm{P}<0.01,{ }^{*} * * \mathrm{P}<0.005, \mathrm{~ns}=$ not significant. 
Table 2. Means \pm standard errors $(\mathrm{n}=5)$ of soil chemical data.

\begin{tabular}{lccccrr}
\hline Soil chemical characteristics & \multicolumn{2}{c}{ I (April 2000) } & \multicolumn{2}{c}{ II (October 2000) } & \multicolumn{2}{c}{ III (April 2001) } \\
\cline { 2 - 7 } & \multicolumn{1}{c}{ SM } & IM & SM & IM & SM & 1M \\
\hline pH (H2O) & $8.1 \pm 0.1 \mathrm{a}$ & $7.2 \pm 0.4 \mathrm{~b}$ & $8.2 \pm 0.1 \mathrm{a}$ & $7.5 \pm 0.1 \mathrm{~b}$ & $8.4 \pm 0.2 \mathrm{a}$ & $7.7 \pm 0.8 \mathrm{~b}$ \\
Organic Carbon (g kg-1) & $18.6 \pm 2.2 \mathrm{a}$ & $10.8 \pm 2.2 \mathrm{~b}$ & $18.6 \pm 2.8 \mathrm{a}$ & $12.0 \pm 1.8 \mathrm{~b}$ & $20.8 \pm 1.7 \mathrm{a}$ & $12.9 \pm 1.7 \mathrm{~b}$ \\
Total Nitrogen (g/kg-1) & $1.9 \pm 0.1 \mathrm{a}$ & $1.3 \pm 0.3 \mathrm{~b}$ & $1.9 \pm 0.2 \mathrm{a}$ & $1.2 \pm 0.1 \mathrm{~b}$ & $1.9 \pm 0.2 \mathrm{a}$ & $1.3 \pm 0.2 \mathrm{~b}$ \\
$\mathrm{C} / \mathrm{N}$ & $10.1 \pm 1.3$ & $8.8 \pm 1.5$ & $10.0 \pm 0.6$ & $9.8 \pm 0.6$ & $11.0 \pm 0.6$ & $10.1 \pm 0.6$ \\
Electrical Conductivity(dSm-1) & $0.14 \pm 0.01 \mathrm{c}$ & $0.35 \pm 0.1 \mathrm{ab}$ & $0.23 \pm 0.02 \mathrm{bc}$ & $0.40 \pm 0.1 \mathrm{a}$ & $0.20 \pm 0.1 \mathrm{c}$ & $0.25 \pm 0.1 \mathrm{bc}$
\end{tabular}

Values with the same letter on the same row are not significantly different at $\mathrm{P}<0.05)$ according to Tukey's test. SM $=$ Sustainable Management soil; IM = Intensive Management soil.

dissolution and dispersion in the presence of $\mathrm{Na}^{+}$, followed by erosion and leaching (Nelson and Oades, 1998). Actually the organic matter content in the soil IM, lower than in the SM soil, was due to the lack of organic amendment and to the intensive soil tillage that increase the oxidation of soil organic matter how evidenced, particularly, in soils of semiarid regions (Mann 1986).

No sensible differences were found for the $\mathrm{C} / \mathrm{N}$ ratio, the average value of which was about 10 in all soils (Table 2); this point out a soil organic matter that is stable and well humified though subjected to the mineralization processes that are usual in a Mediterranean climate.

The SM soil was significantly more basic than the IM soil which appeared sub-alkaline (Table 2). This was perhaps due to repeated additions of sulphur powder to the IM soil (Colombo et al., 2002); it is likely that sulphur oxidation to sulphate by Thiobacillus bacteria, was responsible for the lowering of $\mathrm{pH}$ in this soil.

The electrical conductivity (EC) of water extracts (Table 2) was significantly higher in the IM soil than in the SM soil at the first two sampling times (MANAGEMENT*TIME effect, $P$
$<0.05)$. For the same soils, Colombo et al. (2002) have reported only a small increase in sodicity due to salty irrigation waters $(2.5 \%$ and $5.1 \%$ as average levels of Exchangeable Sodium Percentage, respectively for SM and IM soils).

\subsection{Soil biological characteristics}

Potentially Mineralizable N (PMN) resulting from the net mineralization of the soil organic nitrogen pool was measured as the difference between the mineral nitrogen $\left(\mathrm{NO}_{3}-\mathrm{N}\right.$ plus $\mathrm{NH}_{4}-\mathrm{N}$ ) content after 28 days (d 28) of incubation at $30^{\circ} \mathrm{C}$ and that at time zero (d 0), i.e. at the beginning of incubation (Table 3 ). In both soils, mineral $\mathrm{N}$ mainly consisted in $\mathrm{NO}_{3}-\mathrm{N}$ (96$99 \%)$ and marginally in $\mathrm{NH}_{4}-\mathrm{N}(1-4 \%)$. This trend is coherent with the used method under aerobic condition that favoured the fast oxidation to nitrate of ammonium by autotrophic nitrifying bacteria. Therefore, denitrification processes were likely to be negligible. Nitrate also accumulated by the lack of plant assimilation.

In the first sampling time, the PMN was higher in the IM soil than in the SM one, suggesting a higher activity of micro-organisms involved in nitrification process, whereas similar nitrogen mineralization rates in both soils in the

Table 3. Means \pm standard errors $(\mathrm{n}=5)$ of nitrogen mineral forms and potentially mineralizable nitrogen $(\mathrm{PMN})$ data.

\begin{tabular}{|c|c|c|c|c|c|c|}
\hline \multirow[t]{2}{*}{ Mineral N } & \multicolumn{2}{|c|}{ I (April 2000) } & \multicolumn{2}{|c|}{ II (October 2000) } & \multicolumn{2}{|c|}{ III (April 2001) } \\
\hline & SM & IM & SM & IM & SM & $1 \mathrm{M}$ \\
\hline Min.-Nd0 ( $\mu \mathrm{g} g-1)$ & $6.1 \pm 1.8 \quad \mathrm{c}$ & $82.0 \pm 15.1 \mathrm{a}$ & $21.8 \pm 4.0 \mathrm{bc}$ & $28.2 \pm 4.8 \mathrm{bc}$ & $26.3 \pm 6.6 \mathrm{bc}$ & $54.9 \pm 38.0 \mathrm{ab}$ \\
\hline NO3-Nd0 ( $\mu \mathrm{g} g-1)$ & $5.9 \pm 1.7 \quad \mathrm{c}$ & $81.0 \pm 14.3 \mathrm{a}$ & $21.0 \pm 3.8 \mathrm{bc}$ & $27.0 \pm 3.9 \mathrm{bc}$ & $19.3 \pm 6.7 \mathrm{bc}$ & $43.9 \pm 31.2 \mathrm{~b}$ \\
\hline NH4-Nd0 ( $\mu \mathrm{g} g-1)$ & $0.2 \pm 0.1 \quad \mathrm{c}$ & $1.0 \pm 1.3 \mathrm{c}$ & $0.8 \pm 0.3 \mathrm{c}$ & $1.2 \pm 1.0 \mathrm{c}$ & $7.0 \pm 1.0 \mathrm{~b}$ & $11.0 \pm 1.7 \quad \mathrm{a}$ \\
\hline Min.-Nd28 ( $\mu \mathrm{g}$ g-1) & $39.5 \pm 11.3 \mathrm{~b}$ & $159.0 \pm 25.4 \mathrm{a}$ & $35.4 \pm 4.9 \mathrm{~b}$ & $43.7 \pm 7.2 \mathrm{~b}$ & $34.4 \pm 9.3 \mathrm{~b}$ & $56.3 \pm 31.3 \mathrm{~b}$ \\
\hline NO3-Nd28 ( $\mu \mathrm{g} g-1)$ & $38.8 \pm 11.3 b$ & $158.0 \pm 25.6 \mathrm{a}$ & $34.7 \pm 4.9 b$ & $41.9 \pm 7.8 \mathrm{~b}$ & $32.6 \pm 9.7 \mathrm{~b}$ & $54.7 \pm 31.2 \mathrm{~b}$ \\
\hline NH4-Nd28 ( $\mu \mathrm{g}$ g-1) & $0.7 \pm 0.2 \quad a$ & $1.0 \pm 0.5 \quad \mathrm{a}$ & $0.7 \pm 0.2 \mathrm{a}$ & $1.8 \pm 2.1 \mathrm{a}$ & $1.8 \pm 1.5 \mathrm{a}$ & $1.6 \pm 0.4 \quad \mathrm{a}$ \\
\hline PMN $\delta \mathrm{d} 28(\mu \mathrm{g} g-1)$ & $33.4 \pm 12.0 \mathrm{~b}$ & $77.0 \pm 12.2 \mathrm{a}$ & $13.6 \pm 2.6 \mathrm{c}$ & $15.5 \pm 4.2 \mathrm{C}$ & $8.1 \pm 3.1 \mathrm{c}$ & $1.4 \pm 9.9 \mathrm{c}$ \\
\hline
\end{tabular}

Values with the same letter on the same row are not significantly different at $\mathrm{P}<0.05$ ) according to Tukey's test. SM $=\mathrm{Sustain}-$ able Management soil; IM = Intensive Management soil. 
Table 4. Means \pm standard errors $\left(n=5\right.$ per the $1^{\text {st }}$ and $3^{\text {rd }}$ sampling data; $n=3$ per the $2^{\text {nd }}$ sampling data) of soil sterols concentrations.

\begin{tabular}{lcccccc}
\hline Soil sterols & \multicolumn{2}{c}{ I (April 2000) } & \multicolumn{2}{c}{ II (October 2000) } & \multicolumn{2}{c}{ III (April 2001) } \\
\cline { 2 - 7 } & SM & IM & SM & IM & SM & IM \\
\hline Cholesterol $(\mu \mathrm{g} \mathrm{g}-1)$ & $0.8 \pm 0.1 \mathrm{c}$ & $0.2 \pm 0.1 \mathrm{~d}$ & $0.6 \pm 0.1 \mathrm{c}$ & $0.6 \pm 0.1 \mathrm{c}$ & $2.1 \pm 0.2 \mathrm{a}$ & $1.7 \pm 0.2 \mathrm{~b}$ \\
$\beta$-Sitosterol $(\mu \mathrm{g}$ g-1) & $4.4 \pm 0.7 \mathrm{bc}$ & $2.3 \pm 0.5 \mathrm{~d}$ & $4.0 \pm 0.7 \mathrm{~cd}$ & $2.6 \pm 0.5 \mathrm{~d}$ & $6.3 \pm 0.5 \mathrm{a}$ & $5.8 \pm 1.4 \mathrm{ab}$ \\
Ergosterol $(\mu \mathrm{g}$ g-1) & $3.3 \pm 0.4 \mathrm{~b}$ & $1.5 \pm 0.8 \mathrm{~b}$ & $2.2 \pm 0.6 \mathrm{~b}$ & $1.0 \pm 0.2 \mathrm{~b}$ & $11.2 \pm 3.0 \mathrm{a}$ & $9.2 \pm 3.4 \mathrm{a}$ \\
Coprostanol $(\mu \mathrm{g} / \mathrm{g}$ ds) & n.d. & n.d. & n.d. & n.d. & n.d. & n.d. \\
\hline
\end{tabular}

Values with the same letter on the same row are not significantly different at $\mathrm{P}<0.05)$ according to Tukey's test. SM $=$ Sustainable Management soil; IM = Intensive Management soil. Data already reported in Puglisi et al. (2003).

other sampling times were observed (Table 3). Moreover at the second and third sampling time, PMN values were significantly lower than at the first one. Particularly, microbial mineralization activity showed a reduction about of 0.4 to 1.2 order of magnitude from first sampling time to the last one (Table 3). Significantly higher $\mathrm{NH}_{4}-\mathrm{N}$ contents in both soils at third sampling time (Table 3) confirmed a slow downing of mineralization process than others two periods. The Min-N content was higher in the IM soil with respect with the SM one at first sampling time also (Table 3) (TIME*MANAGEMENT effect $\mathrm{P}<0.005$, Table 1), confirming a higher nitrogen availability in this soil. Different authors (Broadbent and Nakashima, 1971; McCormick and Wolf, 1989) noted that enhanced net mineralization in salty soils could derive from desorption/solubilization of endogenous organic matter and from osmotic effects on micro-organisms that were releasing substrates rich in nitrogen and carbon. In spite of that, similar EC values at the first and at the second sampling times in the IM soil (Table 2) did not suggest any implication of soil salt content on nitrification activity. On the contrary, what reported at first sampling time could be due to the different fertilizer management in the two soils; the high $\mathrm{NO}_{3}-\mathrm{N}$ levels in the IM soil (Table 3) (TIME effect $\mathrm{P}<0.05$, Table 1 ), in fact, were comparable to the contents of inorganic $\mathrm{N}$ detected in recently fertilized agricultural soils (Meli et al., 2002). Our results, however, show that ammonium oxidizing micro-organisms tolerate moderate saline conditions well. Sterols data for these soils have been already published (Puglisi et al., 2003) and have been used here in order to relate them with other chemical and biological properties.

Coprostanol is an important bio-marker of fecal contamination (González-Oreja and SaizSalinas, 1998). As said before, it was absent in all the samples, thus indicating no fecal pollution in these soils (Table 4).

$\beta$-sitosterol is the main vegetal sterol; its concentration increases during plant development and it represents more than $70 \%$ of all sterols found in several species (Ebraimzadeh et al., 2001). No significant differences were detected by mixed model ANOVA for this sterol (Table 1). Tukey's test for comparison of means, besides, evidenced $\beta$-sitosterol higher contents in the SM soil than the IM one only at first sampling time, showing for both soils the higher levels at third sampling time than the others periods (Table 4). This statistical analysis, differently of ANOVA, confirm what reported by Bull et al. (2000) which evidenced that this bio-indicator is related to soil management and decomposing plant matter.

TIME effect was significant for cholesterol $(P<0.05)$ and ergosterol $(P<0.005)$ (Table 1$)$; both these sterols had a higher concentration at the third sampling equally to $\beta$-sitosterol (Table 4).

Cholesterol, an indicator of micro and mesofauna biomass in soils (Ibanez et al., 2000), was lower in the IM soil at spring time (first and third sampling times, Table 4; TIME*MANAGEMENT effect, Table 1). Its soil content, however, was influenced by organic amendment according to Ibanez et al. (2000).

The MANAGEMENT effect (Table 1) was significant for ergosterol (average concentration was $3.9 \mu \mathrm{g} \mathrm{g}^{-1}$ in the IM soil and $5.6 \mu \mathrm{g} \mathrm{g}^{-1}$ in the SM soil), considered an indicator of living fungal biomass in soils (Stahl and Parkin, 1996). Its soil content was increased more by ecological soil management than conventional one, according to Castillo and Joergensen (2001). It is 
Table 5. Principal component analysis performed after a varimax rotation on the chemical and biological parameters studied. For each axis (factor) the scores of each variable, which express the weight on the factor and the proportion of variance explained by each factor, are reported. Scores $>$ [0.7] are in bold letters.

\begin{tabular}{|c|c|c|}
\hline Soil Quality Indicators & Factor 1 & Factor 2 \\
\hline Cholesterol & 0.94 & 0.24 \\
\hline B-sitosterol & 0.87 & 0.36 \\
\hline Ergosterol & 0.93 & 0.05 \\
\hline $\mathrm{pH}\left(\mathrm{H}_{2} \mathrm{O}\right)$ & 0.16 & 0.86 \\
\hline Organic C & 0.26 & 0.92 \\
\hline Total N & 0.06 & 0.93 \\
\hline Electrical Conductivity & -0.30 & -031 \\
\hline PMN $\delta 28$ days & -0.77 & -0.17 \\
\hline Proportion of variance explained & $40.90 \%$ & $39.20 \%$ \\
\hline
\end{tabular}

well known, moreover, that organic amendment increase ergosterol soil concentration (West et al., 1987). This result is in good accordance with the evidences reported by Crecchio et al. (2004), about the same orchards, which recorded that the soil ATP contents, used either as a estimate of soil biomass size (Sparling and Eiland, 1983) or microbial activity (Fairbanks et al., 1984), were significantly affected by cropping system, being lower in IM soil than SM one. The remarkable ergosterol increment at third sampling time than the others two (Table 4) could be related to the variability of its content reported in natural soil environments (Newell 1992); nevertheless, it is known that the ergosterol content of fungal cells varies depending on species and environmental conditions (Tunlid and White, 1992). At the same time, particularly, soil ATP contents rose significantly (Crecchio et al., 2004). This evidence is coherent with the rising of sterols (Table 4) which were negatively cor-



Figure 1. Principal component analysis after a varimax rotation on the chemical and biological parameters studied. Sustainable Management soil is in white, Intensive Management soil is in black. Squares, triangles and diamonds refer respectively to the first, the second and the third sampling data. related with PMN (Table 5), confirming $\mathrm{N}$ immobilization by soil living organisms.

\subsection{Principal Component Analysis}

All data were analyzed by means of PCA followed by varimax rotation. A clear distinction among groups of variables was obtained (Table 5). Sterols and PMN were weighted on the first axis, while all chemical properties were on the second one (Table 5). Scores of the first two axes $(40.90 \%$ and $39.20 \%$ of variance explained each) were plotted on a two-dimension chart (Figure 1). IM soil was separated from SM soil along the second axis, while samples of the third sampling time were separated from the others along the first axis; nevertheless a distinction on this axis between the IM soil and the SM soil was confirmed (Figure 1).

PCA results are useful when it is possible to identify and give meaningful global names to homogeneous groups of variables that contribute to the definition of some axes. In this case we have: I - an axis of chemical properties (Table 5), which separate IM from SM soils; II - an axis of the three sterols and of the PMN strongly correlated each together (Table 5), which separates the third sampling data from the other data confirming the separation between IM and SM soils. It is related to all the significant variables for the MANAGEMENT effect of ANOVA: organic carbon, total nitrogen, and $\mathrm{pH}$ (Table 1); moreover it is related to electrical conductivity of soil extract which is significant for the TIME*MANAGEMENT interaction (Table 1). This axis from here may be called "MANAGEMENT" axis.

The first axis is related to soil biological properties, sterols and PMN. Among them, er- 
gosterol and cholesterol are significant for the TIME effect as well as for MANAGEMENT effect and TIME*MANAGEMENT interaction respectively, while PMN is significant only for the TIME*MANAGEMENT interaction; therefore this axis may be called "TIME" axis.

What was shown by PCA is that all chemical properties were more affected by crop management than by sampling time. The opposite was true especially for sterols and PMN, which changed mostly with sampling time showing a major sensitivity respect to TIME factor. The reason why these bio-markers showed so high differences along the sampling times may be due to agronomic and/or climatic different conditions occurred but, this could be answered only by a conduction of a long-term experiment.

\section{Conclusions}

Twenty years of horticultural management characterized by intensive soil tillage and low organic matter input, changed soil chemical properties decreasing significantly the levels of organic carbon and total nitrogen when compared with a sustainable agricultural management. Irrigation with moderately saline water had not increase so hardly the salt concentration of soil which did not show sodic properties

PMN was higher in IM soil at the first sampling time only, whereas the three sterols object of study were affected by different soil management and by sampling time: $\beta$-sitosterol, cholesterol and ergosterol changed significantly with time, showing higher levels at the third sampling time. Particularly, ergosterol content was found to be a reliable bio-indicator of intensive horticultural management.

The higher content of the sterolic bio-markers in SM soil even though the evidenced season variability, indicated a higher biological activity in this soil compared with the IM one, thus showing the harmful effects of a lack of organic amendment and of intensive soil tillage on the microbial biomass. On the contrary, it seems that water irrigation quality had not inhibited soil micro-organisms growth like showed by PMN data.

PCA analysis evidenced that intensive and sustainable managements were strongly related to the chemical properties, sterols and PMN were instead remarkably influenced by sampling times. The chemical soil properties, together with soil bio-indicator object of study, were confirmed, particularly in the short term, like applicable and valid soil quality indicators. This was better highlight by the use of both univariate and multivariate statistical analyses.

Further researches involving different soils subjected to managements similar to the one described here are however needed in order to extend and confirm the conclusions drawn from the two soils studied here.

\section{Acknowledgements}

This research was supported by the MIUR (Italian Ministry of University, Scientific and Technological Research) PRIN program (Contract n. 9907027947-005).

\section{References}

Arshad M.A., Coen G.M. 1992. Characterization of soil quality: physical and chemical criteria. Am. J. Altern. Agric., 7:25-31.

Bolinder M.A., Angers D.A., Gregorich E.G., Carter M.R. 1999. The response of soil quality indicators to conservation management. Canadian Journal Soil Science, 79:37-45.

Broadbent F.E., Nakashima T. 1971. Effect of added salts on nitrogen mineralization in three Californian soils. Soil Science Society of America Proceedings, 35:457460.

Bull I.D., van Bergen P.F., Nott P.R., Poulton P.R., Evershed R.P. 2000. Organic geochemical studies of soils from the Rothamsted Classical Experiments-V. The fate of lipids in different long-term experiments. Organic Geochemistry, 31:389-408.

Castillo X., Joergensen R.G. 2001. Impact of ecological and conventional arable management systems on chemical and biological soil quality indices in Nicaragua. Soil Biology and Biochemestry, 33:1591-1597.

Crecchio C., Gelsomino A., Ambrosoli R., Minati J.L., Ruggiero P. 2004. Functional and molecular responses of soil microbial communities under differing soil management practices. Soil Biology and Biochemistry, 36:1873-1883.

Drinkwater L.E., Cambardella C.A., Reeder J.D., Rice C.W. 1996. Potentially mineralizable nitrogen as an indicator of biologically active soil nitrogen. In: Doran J.W., Jones (eds.): Methods for Assessing Soil Quality, Madison, WI-USA.

Duxbury J.M., Nkambule S.V. 1994. Assessment and significance of biologically active soil organic nitrogen. In: Doran J.W., Coleman D.C., Bezdicek D.F., Stewart B.A. (eds.): Defining soil quality for a sustainable environment, Madison, WI-USA. 
Ebrahimzadeh H., Niknam V., Maassoumi A.A. 2001. The sterols of Astragalus species from Iran: GLC separation and quantification. Biochemical Systematics and Ecology, 29:393-404.

Fairbanks B.C., Woods L.E., Bryant R.J., Elliot E.T., Cole C.V., Coleman D.C. 1984. Limitations of ATP estimates of microbial biomass. Soil Biology and Biochemistry, 16:549-558.

González-Oreja J., Saiz-Salinas J.I. 1998. Short-term spatio-temporal changes in urban pollution by means of faecal sterols analysis. Marine Pollution Bullettin, 36:868-875.

Grant W.D., West A.W.J. 1986. Measurement of ergosterol, diaminopimelic acid and glucosamine in soils: evaluation as indicators of microbial biomass. Journal Microbiological Methods, 6:47-53.

Ibanez E., Borrós S., Comellas L.I. 2000. Quantification of sterols. $5 \alpha$ - and $5 \beta$-stanols in sewage sludge: manure and soils amended with both these potential fertilizers. Journal of Analytical Chemistry, 36:102-105.

Keeney D.R., Nelson D.W. 1982. Nitrogen-inorganic forms. In: Page A.L., Miller R.H., Keeney D.R. (eds.): Methods of Soil Analysis - Part 2: Chemical and Microbiological Properties, 643-698. American Society of Agronomy Inc. - Soil Science Society of America, Madison, WI-USA.

Mann L.K. 1986. Changes in soil carbon storage after cultivation. Soil Science, 142:279-288.

Meli S., Porto M., Belligno A., Bufo S.A., Mazzatura A., Scopa A. 2002. Influence of irrigation with lagooned urban wastewater on chemical and microbiological soil parameters in a citrus orchard under mediterranean condition. The Science of the Total Environment, 285:69-77.

McCormick R.W., Wolf D.C. 1989. Effect of sodium cloride on $\mathrm{CO}_{2}$ evolution, ammonification and nitrification in a Sassafras sandy loam. Soil Biology and Biochemistry, 12:153-157.

Nelson P.N., Oades J.M. 1998. Organic matter, sodicity and soil structure. In: Sumner M.E., Naidu R. (eds.): Sodic Soils, 67-91. Oxford University Press, New York.
Newell S.Y. 1992. Estimating fungal biomass and productivity in decomposing litter. In: Carrol G.C., Wicklow D.T. (eds.): The Fungal Community: Its Organization and Role in the Ecosystem, 521-561. Marcel Dekker, New York.

Page A.L., Miller R.H., Keeney D.R. 1982. Methods of Soil Analysis. Part 2: Chemical and Microbiological Properties American Society of Agronomy Inc. - Soil Science Society of America, Madison, WI.

Puglisi E., Nicelli M., Capri E., Trevisan M., Del Re A.A.M. 2003. Cholesterol, ß-sitosterol, ergsoterol and coprostanol in agricultural soils. Journal of Environmental Quality, 32:466-471.

SAS Institute 1985. SAS User's Guide: Statistics. Version $5^{\text {th }}$. Inc. Cary, NC, USA.

Sit V. 1995. Analyzing ANOVA designs. Biometrics Information Handbook N. 5 - Working Paper 07, Research Branch, B.C. Ministry of Forestry, Victoria, BC.

Snedecor G.W., Cochran W.G. 1989. Statistical Methods, $8^{\text {th }}$ edition, Iowa State University Press, Ames, Iowa.

Sparling G.P., Eiland F. 1983. A comparison of methods for measuring ATP and microbial biomass in soils. Soil Biology and Biochemistry, 15:227-229.

Stahl P.D., Parkin T.B. 1996. Relationship of soil ergosterol concentration and fungal biomass. Soil Biology and Biochemistry, 7:847-855.

Tunlid A., White D.C. 1992 Biochemical analysis of biomass, community structure, nutritional status and metabolic activity of microbial communities in soil. Soil Biology and Biochemistry, 7:229-262.

West A.W., Grant W.D., Sparling G.P. 1987. Use of ergosterol, diaminopimelic acid and glucosamine content of soils to monitor changes in microbial populations. Soil Biology and Biochemistry, 19:607-612.

Zalidis G., Stamadiatis S., Takavakoglou V., Eskridge K., Misopolinos N. 2002. Impacts of agricultural practices on soil and water quality in the Mediterranean region and proposed methodology. Agriculture, Ecosystems and Environments, 88:137-146. 